\title{
PERANAN INFORMASI AKUNTANSI PERTANGGUNGJAWABAN DALAM PENILAIAN LAPORAN KEUANGAN PT. ARTA SEDANA TAHUN 2016
}

\author{
Desak Kadek Novitayanti \\ Jurusan Pendidikan Ekonomi, Fakultas Ekonomi \\ Universitas Pendidikan Ganesha Singaraja, \\ Indonesia \\ e-mail: novitha728@yahoo.com
}

\begin{abstract}
Abstrak
Penelitian ini bertujuan untuk mengetahui peranan informasi akuntansi pertanggungjawaban dalam penilaian keuangan, dan hasil pengukuran kinerja pusat-pusat pertanggungjawaban pada PT. Arta Sedana. Subjek dalam penelitian ini adalah PT. Arta Sedana, Sedangkan Objeknya adalah bagaimana analisis akuntansi pertanggungjawaban dalam menilai laporan keuangan pada PT. Arta sedana. Penelitian ini menggunakan desain deskriptif. Data yang dikumpulkan dengan metode dokumentasi yang selanjutanya dianalisis dengan analisis deskriptif kuantitatif. Hasil penelitian ini menunjukkan bahwa peranan informasi akuntansi pertanggungjawaban pada PT. Arta Sedana Tahun 2016 sudah cukup memadai karena telah memenuhi syarat pertanggungjawaban. Hasil kinerja pusat-pusat pertanggungjawaban ditinjau dari akuntansi pertanggungjawaban berdasarkan analisis data (a) pusat biaya yaitu PT. Arta Sedana tahun 2016 dapat dilihat total biaya yang dianggarakan sebesar Rp 18.270.000.000 dan biaya sesungguhnya sebesar Rp. 17.996.250.000 sehingga mendapatkan selisih laba sebesar Rp. 273.750.000, (b) pusat pendapatan, total pendapatan yang dianggarakan sebesar Rp. 64.650.000.000 sedangkan pendapatan sesungguhnya yang diperoleh sebesar Rp. 67.977.750.000, pusat pendapatan menghasilkan selisih laba sebesar Rp. 3.327.750.000, (c) pusat laba, dengan menggunakan analisis gross profit margin menunjukkan hasil yang merugikan, analisis operating profit margin dan net profit margin menunjukkan hasil yang menguntungkan.
\end{abstract}

Kata Kunci: informasi akuntansi pertanggungjawaban, penilaian laporan keuangan, peranan akuntansi

\begin{abstract}
This study aims to determine the role of information responsibility accounting in financial valuation, Performance measurement results of responsibility centers at PT. Arta Sedana. Subjects in this study were PT. Arta Sedana, While the object is how accountancy analysis accounting in assessing financial statements at PT. Arta sedana. This research uses descriptive design. The data collected by documentation method are analyzed by descriptive quantitative analysis. The results of this study indicate that the role of information responsibility accounting at PT. Arta Sedana The year 2016 is sufficient because it has fulfilled the requirements of responsibility accounting. Performance result of responsibility centers evaluated from accountancy of responsibility based on data analysis (a) cost center that is PT. Arta Sedana 2016 can be seen the total cost of Rp 18,270,000,000 and the actual cost of Rp. 17.996.250.000 so get the profit margin of Rp. 273.750.000, (b) revenue center, the total income of Rp. 64.650 .000 .000 while the actual income earned is Rp. 67.977.750.000. The revenue center generates a profit margin of Rp. 3.327.750.000, (c) profit centers, using gross profit margin analysis show adverse outcomes, analysis of operating profit margin and net profit margin indicate favorable outcomes.
\end{abstract}

Keywords: information responsibility accounting, Assessment of financial Statements, Accounting roles 


\section{PENDAHULUAN}

Semakin

berkembangnya perekonomian yang terjadi di Indonesia maka perusahaan semakin dituntut untuk dapat meningkatkan kinerjanya. Menurut Mulyadi (2001:174) "salah satu usaha yang dilakukan perusahaan yang profit motive (mencari laba) untuk mempertahankan kelangsungan hidupnya dan memperluas bisnisnya adalah dengan menciptakan sumber daya manusia yang dimiliki oleh suatu perusahaan". Dalam usaha untuk mencapai tujuannya, maka setiap perusahaan harus mempersiapkan secara matang serta meningkatkan etos kerja secara profesional untuk meningkatkan kinerja perusahaan agar dapat mencapai tujuan yang telah ditetapkan dan dapat bersaing dengan perusahaan lainnya, baik domestik maupun internasional (Handayani, 2010:1).

Perusahaan merupakan wadah kegiatan dalam menjalankan kegiatan usaha, yang dipimpin oleh seorang karyawan dimana karyawan tersebut mengemban tugas menjalankan proses kegiatan mengoperasikan perusahaan tersebut. Setiap unit organisasi merupakan pusat pertanggungjawaban maka setiap pimpinan pusat pertanggungjawaban akan memberikan informasi baik berupa anggaran maupun laporan manajemen. Menurut Mulyadi (2005) akuntansi pertanggungjawaban adalah Suatu sistem akuntansi yang disusun sedemikian rupa sehingga pengumpulan serta pelaporan biaya dan pendapatan dilakukan sesuai dengan pusat pertanggungjawaban dalam organisasi, dengan tujuan agar dapat ditunjuk orang atau kelompok orang yang bertanggungjawab atas penyimpangan biaya dan/atau pendapatan yang dianggarkan. Penerapan akuntansi pertanggungjawaban yang baik akan membantu manajemen perusahaan untuk menilai kinerja setiap pusat pertanggungjawaban dalam rangka pengambilan keputusan dan mencapai tujuan perusahaan secara menyeluruh. Informasi akuntansi pertanggungjawaban merupakan informasi yang penting dalam proses perencanaan dan pengendalian aktivitas organisasi, karena informasi tersebut menekankan hubungan antara informasi dengan manager yang bertanggungjawab terhadap perencanaan dan realisasinya.

Sistem

akuntansi pertanggungjawaban memerlukan penyusunan anggaran. Menurut Hariadi (2002), anggaran adalah rencana yang dinyatakan dengan angka-angka moneter yang biasanya mencakup jangka waktu satu tahun. Anggaran yang dibuat merupakan suatu pengarahan atas perhatian, karena membantu para manajer untuk memusatkan perhatian pada masalah operasional atau keuangan pada waktu yang lebih awal untuk pengendalian yang lebih efektif. Oleh karena itu, haruslah disusun anggaran untuk tiap-tiap tingkatan manajemen melalui pembentukan pusat-pusat pertanggungjawaban, serta laporan anggaran dan realisasinya dari setiap pusat pertanggungjawaban untuk dapat menentukan prestasi pusat pertanggungjawaban.

Untuk menetapkan budget pada tiap-tiap pusat pertanggungjawaban harus sudah diklasifikasikan biaya yang dapat dikendalikan dan yang tidak dapat dikendalikan pusat-pusat tersebut. Setiap unit organisasi yang disiapkan laporan prestasinya disebut pusat pertanggungjawaban. Menurut Widjaja (1996:243) menyatakan "pusat pertanggungjawaban adalah area dari suatu organisasi yang disegmentasikan dengan manajer mempunyai tanggungjawab terhadap area tertentu".

Menurut Mulyadi (2005:205),
"manfaat informasi akuntansi
pertanggungjawaban adalah informasi
akuntansi pertanggungjawaban yang
berupa informasi yang akan datang


bermanfaat untuk penyusunan anggaran di periode berikutnya". Informasi akuntansi pertangunggjawaban bermanfaat untuk memperjelas peran seorang manajer sebab dalam penyusunan anggaran, ditetapkan siapa atau pihak mana yang bertanggungjawab atas pelaksanaan kegiatan pencapaian tujuan perusahaan, juga ditetapkan sumber daya (yang disusun dalam satuan mata uang) yang disediakan bagi pemegang tanggungjawab tersebut untuk melaksanakan kegiatan itu. Penilaian kinerja merupakan penilaian atas perilaku manusia dalam melaksanakan peran yang mereka miliki dalam organisasi, jika informasi akuntansi merupakan salah satu dasar penilaian kinerja maka informasi itu terkait dengan akuntansi manajemen yang dihubungkan dengan individu yang memiliki peran dalam organisasi yang merupakan informasi akuntansi manajemen. Mulyadi (2001) menyatakan bahwa penilaian kinerja akan berjalan secara efektif apabila didalamnya telah diklasifikasikan dengan jelas pusat-pusat pertanggungjawaban yang menjadi tanggung jawabnya yang dapat dibedakan menjadi pusat biaya, pusat pendapatan, pusat laba dan pusat investasi. Dalam system penghargaan perusahaan, informasi akuntansi merupakan bagian yang penting.

Informasi tersebut merupakan datadata perusahaan, baik yang belum diproses maupun yang telah diproses sebelumnya. Informasi secara garis besar dibagi menjadi dua, yaitu informasi kualitatif dan informasi kuantitatif. Salah satu bentuk informasi kuantitatif adalah informasi akuntansi manajemen karena informasi menggunakan satuan uang sebagai ukurannya. Terdapat tiga tipe informasi akuntansi manajemen, yaitu informasi akuntansi penuh, informasi akuntansi diferensial dan informasi akuntansi pertanggungjawaban. Ketiga informasi akuntansi manajemen tersebut dapat meliputi aktiva, pendapatan, dan biaya, yang menyangkut informasi masa lalu dan informasi masa yang akan datang, tergantung untuk apa informasi tersebut disajikan.

Adapun peranan bagi perusahaan disini yaitu PT. Arta Sedana Singaraja khusus informasi akuntansi pertanggungjawaban merupakan informasi yang penting dalam proses perencanaan dan pengendalian manajemen karena informasi tersebut menekankan hubungan antar informasi keuangan dengan karyawan yang bertanggung jawab terhadap perencanaan, pengendalian dan pelaksanaannya. Pengendalian dapat dilakukan dengan cara memberikan peran bagi setiap karyawan untuk merencanakan pendapatan dan/atau biaya dengan aktiva yang digunakan untuk menghasilkan pendapatan yang menjadi tanggung jawabnya dan kemudian menyajikan informasi realisasi pendapatan dan biaya tersebut menurut karyawan yang bertanggungjawab. Dengan demikian, informasi akuntansi pertanggungjawaban mencerminkan skor (score) yang dibuat setiap karyawan dalam menggunakan berbagai sumber daya untuk melaksanakan peran karyawan tersebut dalam mencapai sasaran perusahaan. Informasi akuntansi pertanggungjawaban diperlukan untuk memantau sampai seberapa jauh setiap karyawan yang bertanggung-jawab atas pusat pertanggungjawabannya tertentu dapat melaksanakan rencananya.

PT.Arta Sedana yang semula berstatus sebagai Perseroan Komanditer (CV) menjadi Perseroan terbatas (PT). Pada masa Perseroan Komanditer (CV) kewenangan dan aktivitas perusahaan tersentralisasi di kantor pusat, maka dalam struktur organisasi yang baru perubahan besar telah terjadi, di mana terlihat desentralisasi dan delegasi mulai secara tegas diberikan kepada PT.Arta Sedana, sementara kantor pusat lebih berfungsi sebagai fasilitator dan unit pendukung. Perubahan status tersebut, mengakibatkan peranan karyawan sangat 
dominan dalam pengambilan keputusan strategik agar salah satu tujuan utamanya yaitu dapat mengendalikan biaya dapat tercapai. Dalam menghadapi perubahan tersebut, manajemen memerlukan informasi akuntansi pertanggungjawaban yang dapat digunakan untuk menyiapkan Budget untuk masing-masing responsibility center, mengukur Performa dari masing-masing responsibility center, menyiapkan skema pelaporan secara periodik yang membandingkan jumlah secara aktual dan jumlah di karenakan pada sistem terdahulu perusahaan hanya menggunakan sistem apabila memperoleh keuntungan maka sudah mendapatkan pertanggungjawaban yang baik.

Berdasarakan penelitian awal,
dapat diketahui pendapatan yang dianggarkan oleh PT. Arta Sedana Pada Tahun 2016 sebesar Rp. 62.520.000.000, biaya yang dianggarkan sebesar $\mathrm{Rp}$. 16.720.000.000 dan laba yang dianggarkan sebesar Rp. 45.800.000, sedangkan pendapatan sesungguhnya sebesar Rp. 65.650.000.000, pengeluaran sebesar Rp. 15.550.000.000 dan perolehan laba sebesar $\mathrm{Rp}$. 50.100.000. Dilihat dari data yang dipaparkan tersebut, pendapatan yang dianggarkan lebih kecil dari pendapatan sesungguhnya sehingga menghasilkan selisi laba, sedangkan biaya yang di anggarkan lebih besar dari biaya sesungguhnya yang juga menghasilkan selisih laba. Begitu pula dengan laba yang diproleh lebih besar dari laba yang dianggarkan sehingga menghasilkan selisih laba.

Dari data tersebut maka informasi akuntansi pertanggungjawaban merupakan informasi akuntansi yang penting dalam proses perencanaan dan pengendalian aktivitas organisasi dan dapat dijadikan sebagai dasar untuk menganalisis kinerja keuangan dan sekaligus tercapainya tujuan perusahaan. Dalam akuntansi pertanggungjawaban, laporan prestasi disiapkan untuk setiap segmen. Segmen dapat berupa departemen, bagian-bagian yang lebih kecil dari departemen, atau sekelompok departemen yang beroperasi di bawah kendali dan wewenang seorang manajer yang bertanggungjawab. Setiap unit organisasi yang disiapkan laporan prestasinya disebut pusat pertanggngjawaban, sehingga pusat pertanggungjawaban adalah suatu segmen atau bagian dalam organisasi perusahan yang dipimpin oleh manajer dan diberi wewenang dan tanggungjawab atas seperangkat aktivitas tertentu. Menurut Mulyadi (2001:422) "pusat pertanggungjawaban adalah suatu unit organisasi yang dipimpin oleh seseorang manajer yang bertanggungjawab".

Berdasarkan definisi pusat pertanggungjawaban di atas dapat disimpulkan bahwa pusat pertanggungjawaban adalah suatu unit organisasi yang dipimpin oleh seorang manajer yang mempunyai wewenang dan tanggungjawab atas aktivitas yang dilaksanakan oleh unit yang dipimpinnya. Untuk tujuan evaluasi prestasi keuangan, pusat-pusat pertanggungjawaban diklasifikasikan menjadi pusat biaya, pusat pendapatan, pusat laba dan pusat investasi. Berdasarkan latar belakang penelitian yang telah dikemukakan di atas, penulis tertarik untuk mengadakan suatu penelitian dan menuangkannya dalam skripsi yang berjudul "Peranan Informasi Akuntansi Pertanggungjawaban Dalam Penilaian Laporan Keuangan PT. Arta Sedana Tahun 2016“

Penelitian ini bertujuan untuk mengetahui peranan Informasi Akuntansi Pertanggungjawaban dalam Penilaian Keuangan, dan hasil pengukuran kinerja pusat-pusat pertanggungjawaban pada PT. Arta Sedana Tahun 2016.

\section{METODE}

Penelitian ini dilakukan untuk mengetahui peranan Informasi Akuntansi Pertanggungjawaban dalam penilaian keuangan PT. Arta Sedana. Penelitian ini 
menggunakan metode deskriptif dengan pendekatan kuantitatif yang bertujuan untuk menggambarkan fenomena yang terjadi dengan menggunakan angkaangka.

Subjek dalam penelitian ini adalah PT. Arta Sedana, sedangkan objek penelitian adalah bagaimana peranan akuntansi pertanggungjawaban dalam menilai laporan keuangan PT. Arta sedana. Data yang digunakan dalam penelitian ini berdasarkan sumbernya adalah data sekunder. Data sekudender yaitu berupa laporan keuangan yang diperoleh dari PT. Arta Sedana meliputi laporan laba rugi, laporan neraca, serta anggaran tahun 2016.

Penelitian ini menggunakan analisis data Kuantitatif berupa angka-angak yang dapat dihitung dan mebahasnya menggunakan analisis deskriptif. Pengumpulan data dilakukan dengan metode dokumentasi yaitu pengumpulan data dilakukan dengan melihat dan mempelajari catatan-catatan serta dokumen yang berhubungan langsung dengan akuntansi pertanggungjawaban pada perusahaan. Data yang diproleh melalui metode dokumentasi ini berupa laporan laba rugi dan laporaan neraca PT. Arta Sedana tahun 2016

Dalam penelitian ini, akan dilakukan teknik atau metode analisis data berupa analisis kuantitatif. Dalam penelitian ini aspek yang digunakan untuk mengukur kinerja sebagai berikut. Pusat Biaya Jika biaya sesungguhnya lebih kecil dari anggaran biaya maka dapat disebut selisih menguntungkan namun, jika biaya sesungguhnya lebih besar dari anggaran biaya maka dapat dikatakan selisih merugikan

Analisis pusat pendapatan dilakukan dengan membandingkan antara pendapatan yang sesungguhnya dengan pendapatan menurut anggaran, dengan mengganggap selisih sebagai penyimpangan. Kinerja pusat dikatakan baik jika pendapatan sesungguhnya lebih besar dari pada pendapatan yang diangggarkan.

Menurut (Sugiri, 1996:166) "Pusat laba dianalisis dengan membandingkan antara laba yang sesungguhnya dengan laba menurut anggaran". Selain itu terdapat tiga langkah penganalisisan pusat laba yaitu gross profit margin, operating profit margin, net profit margin.

Gross Profit Margin (GPM) "jika Gross Ptofit Margin dalam anggaran lebih kecil dibandingkan dengan sesunggguhnya maka semakin baik keadaan operasional suatu perusahaan" Syamsudin (2002:61). Menurut Munawir (2007) gross profitt margin dihitung dengan rumus,

$$
\text { GPM }=\frac{\text { Laba Kotor }}{\text { Penjualan }} \times 100 \%
$$

Operating Profit Margin (OPM) "Jika Operating Profit Margin yang digunakan leboh kecil dibandingkan dengan yang sesungguhnya, maka semakin baik kegiatan operasi perusahaan" Syamsudin (2002:6). Sedangkan menurut Agnes (2009:91) "operating profit margin menghitung laba operasi yang benarbenar diproleh dari hasil operasi peusahaan dengan mengabaikan kewajiban-kewajiban berupa bunga dan pembayaran pajak". Menurut Munawir (2007:240) operating profitt margin dihitung dengan rumus,

$\mathrm{OPM}=\frac{\text { Laba operagl }}{\text { Penjualan }} \times 100 \%$

Net Profit Margin (NPM) "jika net profit margin dalam anggaran lebih kecil dibandingkan dengan sesungguhnya, maka semakin baik operasi suatu perusahaan" (Syamsudin, 2002:61), Menurut Agnes (2009:18) net profitt margin dihitung dengan rumus,

$N P M=\frac{\text { Laba Bersih }}{\text { Penjualan }} \times 100 \%$ 
Pusat Investasi dapat dianalisis dengan menggunakan metode sebagai berikut. (a) return On Invesment (ROI) Semakin tinggi rasio ini semakin baik keadaan suatu perusahaan. Jika ROI yang dianggarakab lebih kecil dari realisasinya maka kinerja suatu perusahaan dapat dinyatakan mengguntukan. (b) return On Equity, jika ROE yang dianggarakab lebih kecil dari realisasinya maka kinerja suatu perusahaan dapat dinyatakan menguntungkan. (c) residual Income (RI), jika RI dalam anggaran lebih kecil dibandingkan dengan sesungguhnya, maka semakin baik kadaan operasi suatu perusahaan. Jika RI yang dianggarkan lebih kecil dari realisasinya maka kinerja suatu perusahaan dapat dinyatakan menguntungkan. RI dapat dihitung dengan mengurangi laba yang diproleh pusat laba dengan beban modal (capital charge).

Adapun standarisasi yang harus dicapai oleh perusahaan dalam mengukur kinerja perusahaan dapat dilihat dalam tabel

Tabel 1

Standar Industri Rasio Profitabilitas

\begin{tabular}{ccc}
\hline Analisis & $\%$ & Keterangan \\
\hline Gross Profit Margin & $>20 \%$ & Baik \\
Operating Profit margin & $>5$ & Baik \\
Net Profit Margin & $>5 \%$ & Baik \\
\hline
\end{tabular}

Sumber: Kasmir (2012:208)

Apabila perusahaan mencapai net profit margin lebih besar dari 5\%, maka perusahaan di katakan baik karena berada di atas rata-rata industri dan apabila mencapai kurang dari 5, maka perusahaan dikatakan kurang baik di bawah rata - rata industri. Namun perlu juga di perhatikan bahwa persentase anggaran yang di rencanakan harus lebih besar dari realiasi pengeluaran yang terjadi dalam operasional perusahaan, agar perusahaan menerima keuntungan

Apabila perusahaan mencapai Operating Profit Margin lebih kecil dari $5 \%$ maka perusahaan dikatakan mampu manajemen memperoleh ROI karena berada di atas rata-rata industri dan apabila mencapai kurang dari 5\%, maka perusahaan dikatakan kurang mampu manajeme memperoleh ROI. Namun perlu juga di perhatikan bahwa persentase anggaran yang di rencanakan harus lebih besar dari realiasi pengeluaran yang terjadi dalam operasional perusahaan, agar perusahaan menerima keuntungan.

Apabila perusahaan mencapai gross profit margin lebih besar dari $20 \%$, maka perusahaan dikatakan mampu manajemen memperoleh gross profit margin karena berada di atas rata-rata industri dan apabila mencapai lebih besar dari $20 \%$ maka perusahaan dikatakan kurang mampu manajeme memperoleh gross profit margin. Namun perlu juga di perhatikan bahwa persentase anggaran yang di rencanakan harus lebih besar dari realiasi pengeluaran yang terjadi dalam operasional perusahaan, agar perusahaan menerima keuntungan Apabila terbalik maka sudah tentunya perusahaan mengalami kerugian.

\section{HASIL DAN PEMBAHASAN Hasil}

Prosses pencatatan Keuangan PT. Arta Sedana dimulai dari bukti transaksi berupa nota dan kwitansi yang kemudian dicatat kedalam buku jurnal umum. 
Setelah dicatat ke dalam buku jurnal umum lalu diposting kembali kedalam buku besar untuk mengklasifikasikan bukti-bukti transaksi yang bersangkutan yang selanjutnya dicatat ke dalam neraca lajur. Data yang berasal dari neraca lajur, digunkana sebagi sumber informasi untuk menyusun laporan keuangan yang terdiri dari dari neraca, laporan laba rugi dan laporan perubahan modal.

Dilihat dari sistem akuntansi pertanggungjawaban PT. Arta Sedana telah memenuhi syarat akuntansi pertanggungjawaban dengan menyusun anggaran terlebih dahulu sebelum melakukan kegiatan operasional perusahaan. Dimana peran penyusunan anggaran dalam mencapai sasaran perusahaan yaitu pihak manajeman atau perusahaan lebih mudah merencanakan anggaran perusahaan untuk satu periode. Penyusunan anggaran dalam akuntansi pertanggungjawaban juga berperan sebagai pedoman dalam melaksanakan kegiatan operasional perusahaan. Penganggaran yang dilakukan PT. Arta Sedana dengan mempertimbangkan informasi keuangan pada tahun sebelumnya, hal ini dilakukan agar penyusunan anggaran sesuai dengan kondisi yang terjadi. Dimana pada akhir tahun anggaran ini dibandingkan dengan realisasi keuangan yang terjadi. Selisih yang ditimbulkan dari perbandingan tersebut dicatatan dalam laporan pertanggungjawaban dan digunakan sebagai penilaian dalam mencapai sasaran perusahaan. PT. Arta sedana juga telah menyusun laporan pertanggungjawaban, yang dimana peran laporan pertanggungjawaban dalam mencapai sasaran perusahaan adalah untuk memungkinkan perusahaan memproleh informasi biaya yang menggambarkan pemborosan yang dialami perusahan dalam mencapai sasaran perusahaan, sehingga perusahaan akan berupaya untuk melakukan penyempurnaan efisiensi aktivitas penambahan nilai agar dapat mengendalikan besarnya biaya yang dikeluarkan.

Sistem

akuntansi

pertanggungjawaban dianalisis

menggunakan pusat

pertanggungjawaban yang meliputi menganalisi pusat biaya diperlukan rincian mengenai anggaran dan realisasi biaya yang terjadi pada PT. Arta Sedana pada Tahun 2016 untuk membandingkan kinerja sesungguhnya dengan anggaran yang telah ditetapkan. Total biaya yang dianggarakan sebesar Rp 18.270.000.000, dan biaya sesungguhnya sebesar Rp. 17.996.250.000, sehingga, mendapatkan selisih laba sebesar Rp. 273.750.000. Selisih laba ini terjadi karena biaya yang dianggarkan lebih besar dari biaya sesungguhnya.

Pusat Pendapatan diukur dengan dasar pendapatan yang diproleh tanpa memperhatikan biaya atau masukan yang terjadi. Pendapatan dalam hal ini adalah jumlah penjualan barang dan pendapatan lain-lain yang dihasilkan oleh PT. Arta Sedana pada Tahun 2016. Pendapatan yang dianggarakan sebesar $R p$. 64.650.000.000, sedangkan pendapatan sesungguhnya yang diperoleh sebesar Rp. 67.977.750.000. Dalam analisis data pusat pendapatan menghasilkan selisih laba (menguntungkan) sebesar Rp. 3.327.750.000. Selisih laba ini terjadi karena pendapatan yang dianggarkan lebih kecil dari pendapatan sesungguhnya.

Pusat laba dianalisis dengan menggunakan metode Gross Profit Margin (GPM), operating Profit Margin (OPM), dan Net Profit Margin (NPM) yang memerlukan data mengenai anggaran dan realisasi laba usaha, laba kotor, laba bersih, serta laporan penjualan pada PT. Arta Sedana tahun 2016. Berdasarkan analisis data pada tabel di atas, maka hasilya dapat dipaparkan pada tabel 2 . sebagai 
Tabel 2

Hasil analisis Pusat laba

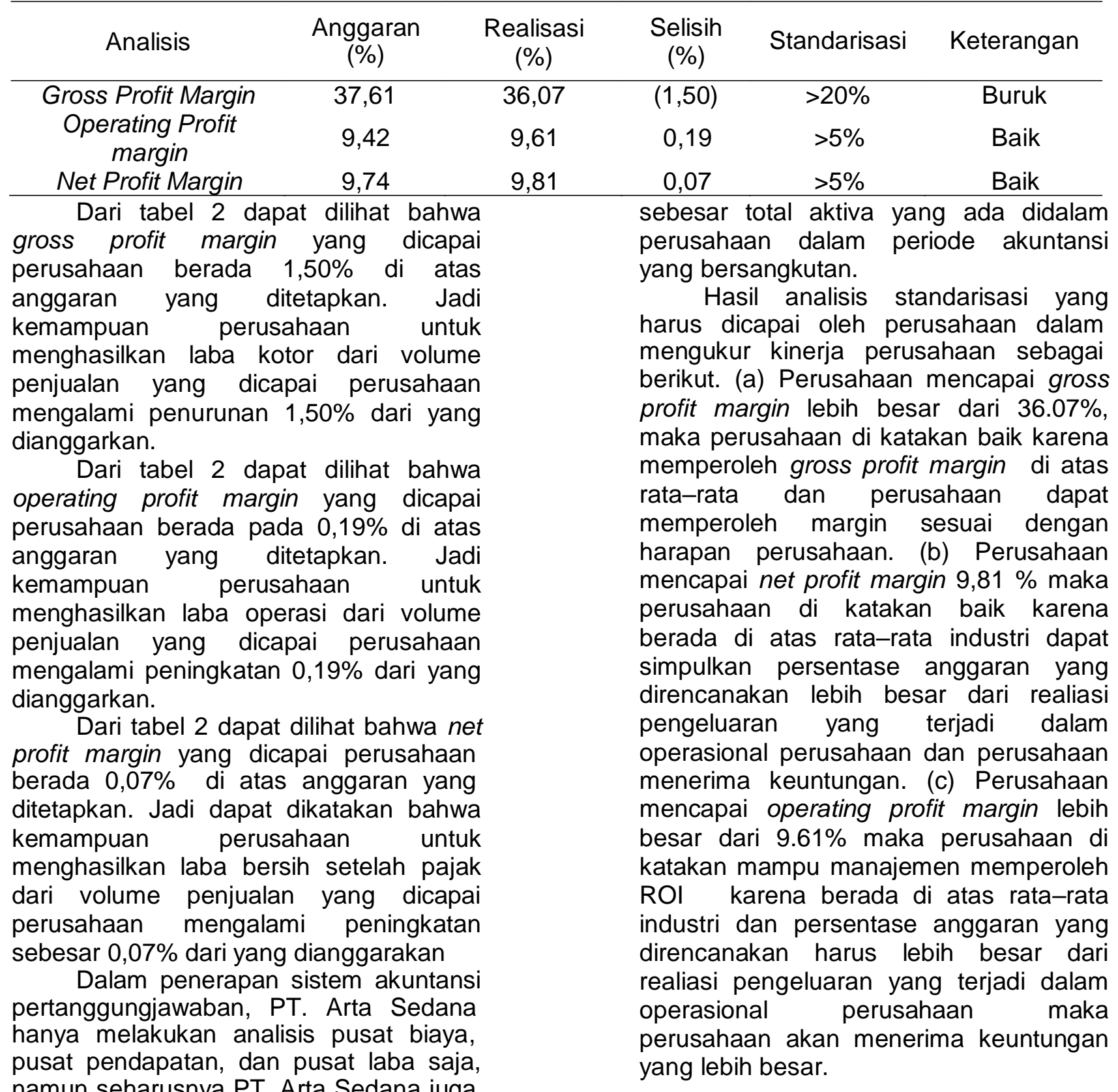
namun seharusnya PT. Arta Sedana juga menganalisis pusat investasi agar perushaan dapat lebih spesifik mengetahui secara nyata hasil kinerja keuangan. Untuk menganalisis pusat investasi, maka perlu ditentukan besarnya investasi yang digunakan dalam perusahaan tersebut. Investasi dihitung

\section{Pembahasan}

Adapun peranan dari akuntansi pertanggungjawaban dalam penilaian laporan keuangan yaitu dimana pihak manajemen lebih mudah dalam merencanakan anggaran perusahaan untuk satu periode dan juga informasi 
akuntansi pertanggungjawaban memungkinkan pemantauan efektivitas program pengelolaan aktivitas manajemen yang memerlukan informasi biaya aktivitas untuk memantau secara berkesinambungan program pengelolaan aktivitas. Dalam penelitian ini, kinerja diukur melalui empat pusat pertanggungjawaban dengan menggunakan kriteria beragam memungkinkan kinerja diukur dari beragam aspek berupa pusat-pusat pertanggungjawaban. Pusat pertanggungjawab tersebut adalah pusat biaya, pusat pendapatan, pusat laba dan pusat investasi. Hal ini sesuai dengan pendapat Mulyadi (2001), pusat pertanggungjawabn dibagi menjadi empat pusat yaitu pusat biaya, pusat pendapatan, pusat laba dan pusat investasi.

Analisis pusat biaya menghasilkan selisih laba karena biaya yang dianggarkan lebih besar dari biaya yang sesungguhnya, sehingga laporan kinerja keuangan perusahaan dapat dinyatakan baik. Hasil ini sesuai dengan teori yang diungkapan Hariadi (2002) bahwa kinerja pusat biaya dikatakan baik jika biaya sesungguhnya lebih kecil dari biaya yang dianggarkan. Analisis pusat pendapatan menghasilkan selisih laba karena pendapatan yang dianggarkan lebih kecil dari pendapatan sesungguhnya, sehingga kinerja keuangan perusahaan dinyatakan baik. Hal ini sejalan dengan teori yang dikemukakan Supriono (2000:364), "kinerja pusat pendapatan dikatakan baik, jika pendapatan sesungguhnya lebih besar daripada pendapatan yang dianggarkan".

Pusat laba dianlisis dengan Gross Profit Margin, Operating Profit Margin, dan Net Profit Margin. Analisis gross profit margin menghasilkan kinerja keuangan perusahaan yang kurang baik. Hasil ini terjadi karena gross profit margin yang dianggarkan lebih besar dari yang sesungguhnya, sehingga menghasilkan selisih rugi. Hal ini disebabkan oleh kenaikan penjualan dari yang dianggarkan dengan yang terjadi sebesar RP. 3.310.500.000,00 Lebih besar dari kenaikan harga pokok produk yang dianggarakan dengan yang terjadi sebesar Rp. 3.105.000.000,00 sehingga mengakibatkan presentasi perolehan laba kotor dibandingkan dengan penjualan yang dianggarkan lebih besar dari yang sesungguhnya. Hasil ini sesuai dengan yang dikemukakan oleh Syamsudin (2002:61) "jika gross profit margin dalam anggaran lebih kecil dibandingkan dengan sesungguhnya maka semakin baik keadaan operasi suatu perushaan".

Analisis operating profit margin menghasilkan selisih laba karena operating profit margin yang dianggarkan lebih kecil dari yang sesungguhnya. Sehingga kinerja laporan keuangan dapat dinyatakan baik. Hasil ini sesuai dengan yang dikemukakan Syamsudin (2002;61), "jika operating profit margin yang dianggarkan lebih kecil dibandingkan dengan sesungguhnya, maka semakin baik kegiatan operasi perusahaan", sedangkan analisis net profit margin menghasilkan selisih laba karena net profit margin yang dianggarkan lebih kecil dibandingkan dengan sesungguhnya, sehingga kinerja keuangan perusahaan dapat dinyatakan baik. Hasil ini sesuai dengan yang dikemukakan Syamsudin, (2002:61) "jika net profit margin dalam anggaran lebih kecil dibandingkan dengan sesungguhnya, maka semakin baik operasi suatu perusahaan".

Hasil di atas memperlihatkan bahwa dengan menerapkan akuntansi pertanggungjawaban, perusahaan dapat melakukan penilaian kinerja. Hal ini sejalan dengan yang diungkapkan oleh Samryn (2001), akuntansi pertanggungjawaban merupakan suatu sistem akuntansi yang digunakan untuk mengukur kinerja setiap pusat pertanggungjawaban sesuai dengan informasi yang dibutuhkan manajer untuk mengoperasikan pusat pertanggungjawaban mereka sebagai 
bagian dari sistem pengendalian manajemen. Pendapat ini membuktikan bahwa sebuah perusahaan yang menginginkan adanya evaluasi kinerja dalam manajemen bisa menerapkan sistem akuntansi pertanggungjawaban sebagai alat penilaian kinerja.

Berdasarkan hasil perhitungan pusat pertanggungjawaban pada PT. Arta Sedana tahun 2016, terdapat hasil merugikan pada pusat laba khususnya kemampuan perusahaan dalam menghasilkan laba kotor dari volume penjualan (gross profit margin). Jika PT. Arta Sedana hanya menganalisis pusat biaya, pendapatan, dan laba seperti tahun-tahun sebelumnya, maka bisa dipastikan kinerja PT. Arta Sedana dinyatakan baik, namun ternyata setelah dianalisis dengan menggunakan empat pusat pertanggungjawaban terdapat hasil yang tidak sesuai pada analisis gross profit margin yang menghasilkan selisih rugi. Dengan mengetahui selisih rugi ini pemilik dapat menindaklanjuti serta memperhatikan tingkat penjualan dan harga pokok produk. Pemilik sebaiknya tidak hanya melihat adanya peningkatan penjualan dan harga pokok produk sesungguhnya saja, namun juga melihat perbandingan antara peningkatan penjualan dan harga pokok produk yang dianggarkan dengan yang sesungguhnya.

Temuan pada penelitian ini sesuai dengan hasil penelitian Widyaastuti (2009) bahwa penerapan akuntansi pertanggungjawaban dapat digunakan sebagai penilaian kinerja dan bahan pertimbangan bagi pimpinan perusahaan dalam mengambil kebijaksanaan dimasa yang akan datang dengan menggunakan analisis pusat pertanggungjawaban.

Penelitian kedua dilakukan oleh Adharawati (2010) dengan hasil penerapan akuntansi pertanggungjawaban dapat digunakan dalam pengendalian biaya dengan menggunakan standar tolak ukur berupa struktur organisasi, penyusunan anggaran, klasifikasi kode rekening, dan penyusunan

laporan

pertanggungjawaban.

\section{SIMPULAN DAN SARAN Simpulan}

Peranan Informasi Akuntansi

Pertanggungjawaban pada PT. Arta Sedana Tahun 2016 sudah cukup memadai karena telah menyusun anggaran dan membuat laporan pertanggungjawaban. Hasil Pengukuran kinerja pusat-pusat pertangungjawaban dilihat dari pusat pertanggungjawaban memperoleh hasil sebagai berikut. (a) Berdasarkan analisis data pusat biaya PT. Arta Sedana tahun 2016 dapat dilihat total biaya yang dianggarakan sebesar Rp 18.270.000.000, dan biaya sesungguhnya sebesar Rp. 17.996.250.000, sehingga, mendapatkan selisih laba sebesar Rp. 273.750.000,. Selisih yang menguntungkan ini terjadi karena biaya yang dianggarkan lebih besar dari biaya sesungguhnya. Pusat biaya menghasilkan selisih menguntungkan, dengan demikian kinerja keuangan perusahaan dapat dinyatakan baik (b) Pendapatan dalam hal ini adalah jumlah penjualan barang dan pendapatan lain - lain yang dihasilkan oleh PT. Arta Sedana pada Tahun 2016. Berdasarkan analisis data pusat pendapatan PT. Arta Sedana dapat dilihat pendapatan yang dianggarakan sebesar Rp. 64.650.000.000,00 sedangkan pendapatan sesungguhnya yang diperoleh sebesar Rp. 67.977.750.000,00. Dalam analisis data pusat pendapatan menghasilkan selisih laba (menguntungkan) sebesar Rp. 3.327.750.000,00 Selisih laba ini terjadi karena pendapatan yang dianggarkan lebih kecil dari pendapatan sesungguhnya. (c) Pusat laba, dengan menggunakan analisis gross profit margin menunjukkan hasil yang merugikan dengan demikian kinerja keuangan perushaan dapat dinyatakan kurang baik, analisis operating profit 
margin dan net profit margin menunjukkan hasil yang menguntungkan.

\section{Saran}

Berdasarkan simpulan di atas, maka dapat dikemukakan saran sebagai berikut. Penilaian kinerja menggunakan akuntansi pertanggungjawaban yang diterapakann PT. Arta Sedana Tahun 2016 tentu akan lebih baik dan lengkap jika dianalisis tidak hanya melalui pusat biaya, pusat pendapatan, dan pusat laba saja namun, juga melalui pusat investasi agar perusahaan secara spesifik mengetahui hasil kinerja perusahaan serta memberikan informasi yang lengkap untuk membantu pemilik membuat kebijakan demi kelangsungan hidup perusahaan. Dalam analisis gross profit margin pada pusat laba menghasilkan hasil yang merugikan, PT. Arta Sedana Singaraja harus dapat meningkatkan penjualan agar dapat meningkatkan pendapatan. Peningkatan penjualan bisa dilakukan dengan mengadakan promosi produk maupun menciptakan motif ukiran baru yang lebih diminati oleh pembeli. Apabila tingkat penjualan naik maka perusahaan akan mendapatkan keuntungan yang lebih banyak sehingga, secara langsung dapat meningkatkan gross profit margin.

\section{DAFTAR PUSTAKA}

Adharawati, Ateha. 2010. "Penerapan Akuntansi Pertanggungjawaban dengan Anggaran sebagai Pengendalian Biaya pada PT. PELNI Cabang Makasar". Skripsi Tidak diterbitkan. Semarang: Fakultas Ekonomi Universitas Diponogoro Semarang.

Agnes, Sawir. 2009. Analisa Kinerja Keuangan dan Perencanaan keauangan Perusahaan.Jakarta: PT. Gramedia Pustaka Utama.
Handayani, Rika. 2010. "Akuntansi Pertanggungjawaban sebagai alat bantu manajamen dalam pengendalian biaya (studi kasus pada PT. Pelabuhan Indonesia I)". Skripsi (tidak diterbitkan). Universitas Sumatera Utara.

Hariadi, Bambang. 2002. Akuntansi Manajemen Suatu Sudut Pandang. Yogyakarta: BPFE.

Kasmir. 2012. Analisis Laporan keuangan. Jakarta: PT Raja Grafindo Persada

Mulyadi. 2001. Akuntansi Manajemen. Jakarta: Salemba Empat 2005. Akuntansi Biaya. Edisi 5. Yogyakarta: UPP AMP YKPN

Munawir. 2007. Analisis Laporan Keuangan, Edisi 4. Jakarta: Salemba Empat.

Syamsudin, Lukman. 2002. Manajemen Keuangan Perusahaan (Konsep Aplikasi Dalam: Perencanaan, Pengawasan dan Pengambilan Keputusan). Edisi Baru. Jakarta: PT. Raja Grafindo Persada.

Sugiri, Slamet dan Bogat Agus Riyono. 1996. Akuntansi Pengantar 1. Yogyakarta: Penerbit VPP AMP YKPN.

Supriono. 2000. Akuntansi Biaya. Yogyakarta: STIE YKPN

Widyastuti.2009." Analisis Akuntansi Pertanggungjawaban pada CV. Santrian Beach Cottage Sanur". Skripsi (tidak diterbitkan). Fakultas Ekonomi. Denpasar: Universitas Mahasaraswati Denpasar.

Widjaja, Amin. 1996. Akuntansi Manajemen Untuk Usahawan. Jakarta: Rineka Cipta. 